\title{
Tinjauan Akad Ijarah dan Peraturan Daerah No. 3 Tahun 2008 tentang Penyelenggara Perparkiran terhadap Pengambilan Sewa Parkir Liar
}

\author{
Rainalia Nadifah S, Eva Misfah Bayuni, Muhammad Yunus \\ Prodi Hukum Ekonomi Syariah, Fakultas Syariah, Universitas Islam Bandung \\ Jl. Tamansari No. 1 Bandung 40116 \\ Rainalia.n@yahoo.com, evambayuni@gmail.com, yunus_rambe@yahoo.co.id
}

\begin{abstract}
Akad Ijarah is an agreement whose object is to redeem the benefits for a particular time, i.e. ownership benefits in return. Ijarah is divided into two kinds, namely Ijarah, which leads to the collection of remuneration (' ala al-A'yan) and Ijarah which leads to wages wage (' ala al-Asykhash) is a service. The background of this research problem is many of which do wild parking or in the government of land road owned by no license but the parking man asks for a fee to the rider who entrust his vehicle to the event of the poll The wild. This research was conducted to answer three problems; 1 . What is the concept of Akad Ijarah according to Fiqh Muamalah? 2. What is the implementation of wild parking rental at Sukahaji Bird market in Bandung? 3. How is the review of Akad Ijarah and regulation of the city of Bandung No. 3 year 2008 about the parking organizers to take a wild car rental? This method of research is a qualitative research method with the type of field research and the nature of qualitative descriptive research. The object of this research is Sukahaji bird market. The data collection techniques in this study are observations and interviews. The results of this study stated that: First, Ijarah is an agreement whose object of redemption benefits in return. Rukun Ijarah There are four, people who berakad, rent, Ijab Qabul, benefits. Secondly, the implementation of parking at Sukahaji Bird Market is divided into two, the official park with the land provided by the market and there are unofficial parking that eat the road. Thirdly, the transaction that occurred in the collection of wild parking rental has not been fulfilled and the requirements of Akad Ijarah and local regulations Bandung City No. 3 year 2008 about the operator of the regulation because there is no agreement in the withdrawal of parking fees, and land That is used does not have a permit to maintenance the parking lot or ownership of the benefits taken not its legitimate property.
\end{abstract}

Keywords-Akad Ijarah, Fiqh Muamalah, wild car Rental collection, Local regulations

Abstrak-Akad Ijarah adalah akad yang objeknya penukaran manfaat untuk masa tertentu, yaitu pemilikan manfaat dengan imbalan. Ijarah dibagi menjadi dua macam yaitu, Ijarah yang mengarah kepada pengambilan imbalan ('ala al-a'yan) dan Ijarah yang mengarah kepada upah mengupah ('ala al-asykhash) yaitu bersifat jasa. Latar belakang masalah penelitian ini banyak yang melakukan parkir liar atau di badan jalan lahan milik pemerintah dengan tidak memiliki ijin akan tetapi tukang parkir meminta biaya kepada pengendara yang menitipkan kendaraannya sehingga terjadinya pemungutan secara liar. Penelitian ini dilakukan untuk menjawab tiga rumusan masalah; 1. Bagaimana ketentuan Akad Ijarah menurut Fikih Muamalah? 2. Bagaimana pelaksanaan pengambilan sewa parkir liar di Pasar Burung Sukahaji Kota Bandung? 3. Bagaimana tinjauan Akad Ijarah dan Peraturan Daerah Kota Bandung No. 3 Tahun 2008 tentang Penyelenggara Perparkiran terhadap pengambilan sewa parkir liar? Metode Penelitian ini adalah Metode penelitian kualitatif dengan jenis penelitian lapangan dan sifat penelitian deskriptif kualitatif. Objek penelitian ini adalah Pasar Burung Sukahaji. Teknik pengumpulan data dalam penelitian ini adalah observasi dan wawancara. Hasil penelitian ini menyatakan bahwa: pertama, Ijarah adalah akad yang objeknya penukaran manfaat dengan imbalan. Rukun Ijarah ada empat, orang yang berakad, uang sewa, ijab qabul, manfaat. Kedua, pelaksanaan parkir di Pasar Burung Sukahaji terbagi dua, parkiran resmi dengan lahan yang disediakan oleh pihak Pasar dan ada parkiran tidak resmi yang memakan badan jalan. Ketiga, transaksi yang terjadi dalam pengambilan sewa parkir liar belum memenuhi rukun dan syarat akad Ijarah dan Peraturan Daerah Kota Bandung No. 3 Tahun 2008 tentang penyelenggara perpakiran karena tidak ada perjanjian dalam penarikan biaya parkir, dan lahan yang digunakan tidak memiliki ijin penyelenggaraan tempat parkir atau kepemilikan manfaat yang diambil bukan milik sah nya.

Kata Kunci-Akad Ijarah, Fikih Muamalah, Pengambilan Sewa Parkir Liar, Peraturan Daerah

\section{PENDAhUluan}

Salah satu prasarana kota yang harus disediakan oleh pemerintah daerah sebagai pengelola kawasan perkotaan adalah menyediakan prasarana parkir, prasarana disini merupakan kondisi sebelum suatu sarana yang harus dipenuhi secara logis. Masyarakat yang mengakhiri perjalanan di Pasar Burung Sukahaji Jalan Peta Kota Bandung karena daerah tersebut adalah tempat yang sering dikunjungi oleh masyarakat.

Dengan adanya peningkatan kendaraan pribadi harus menjadi pertimbangan dalam menyediakan prasarana parkir yang memadai, sehingga terjadi penyimpangan yang dilakukan oleh tukang parkir untuk menghindari kewajiban menanggung segala macam kelalaian, dimana tukang parkir memberlakukan aturan baku secara tersendiri. Pasar Burung Sukahaji Jalan Peta Kota Bandung merupakan pasar yang cukup ramai dikunjungi oleh masyarakat khususnya yang berada di sekitar jalan Peta. 
Berdasarkan observasi awal, penulis melihat ada tukang parkir yang melakukan parkir liar, pelaku yang melakukan tukang parkir liar adalah beberapa orang dewasa, mereka mengelola parkir tersebut dengan orangperorangan dan tidak ada perjanjian diawal pada sewa parkir tersebut tetapi meminta uang yang telah ditentukan oleh pihak tukang parkir tanpa memberikan karcis. Lahan yang dipakai untuk mengelola parkir bukan milik haknya dan tidak diberikan surat keterangan dari pemerintah setempat.

Realita diatas berbanding terbalik dengan Akad Ijarah yang mengharuskan adanya kejelasan di antara kedua belah pihak yang bertransaksi, hal ini selaras dengan Peraturan Daerah No. 3 Kota Bandung Tahun 2008 tentang Penyelenggara Perparkiran yang menyatakan bahwa Setiap badan hukum/per orangan, dilarang menyelenggarakan parkir umum tanpa ijin.

Berdasarkan uraian di atas, penulis tertarik untuk membahas bagaimana praktik pengambilan sewa parkir liar menurut Akad Ijarah dan Peraturan Daerah dalam penelitian yang berjudul "Tinjauan Akad Ijarah dan Peraturan Daerah Kota Bandung No. 3 Tahun 2008 tentang Penyelenggara Perparkiran terhadap Pengambilan Sewa Parkir Liar di Pasar Burung Sukahaji Jalan Peta Kota Bandung". Selanjutnya tujuan dalam penelitian ini diuraikan sebagai berikut:

1. Untuk mengetahui bagaimana ketentuan Akad Ijarah menurut Fikih Muamalah dan Peraturan Daerah Kota Bandung No. 3 Tahun 2008 tentang Penyelenggara Perparkiran.

2. Untuk mengetahui bagaimana pelaksanaan pengambilan parkir liar di Pasar Burung Sukahaji Jalan Peta Kota Bandung.

3. Untuk mengetahui bagaimana tinjauan Akad Ijarah dan Peraturan Daerah Kota Bandung no. 3 Tahun 2008 tentang Penyelenggara Perparkiran terhadap pengambilan parkir liar di Pasar Burung Sukahaji Jalan Peta Kota Bandung.

\section{LANDASAN TEORI}

\section{A. Konsep Akad Ijarah menurut Fikih Muamalah}

Ijarah diambil dari kata Ajr, artinya upah atau balasan. Al-Ijarah dalam Islam diartikan akad pemindahan hak guna atas barang atau jasa, melalui pembayaran upah, tanpa diikuti dengan pemindahan kepemilikan atas barang tersebut.1 Secara lebih sederhana, Ijarah adalah Akad yang objeknya ialah penukaran manfaat untuk masa tertentu, yaitu pemilikan manfaat dengan imbalan, sama dengan menjual manfaat. 2

Landasan hukum Akad Ijarah dalam hukum Islam terdiri dari ayat Alquran dan Hadis, di antaranya adalah:

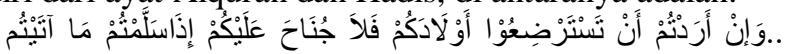

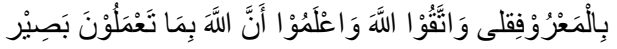

“...Dan jika kamu ingin anakmu disusukan oleh orang lain, maka tidak ada dosa bagimu apabila kamu memberikan pembayaran menurut yang patut. Bertakwalah kamu kepada Allah dan ketahuilah bahwa Allah Maha Melihat apa yang kamu kerjakaan.” (Q.S Al-Baqarah [2]: 233)

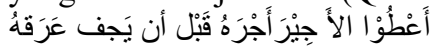

"Berikanlah upah atau jasa kepada orang yang kamu pekerjakan sebelum kering keringat mereka." (HR. Ibnu Majah)

Menurut jumhur ulama, rukun ijarah ada empat sebagai berikut:

1. 'Aqid (orang yang berakad),

2. Ujrah (uang sewa atau upah),

3. Sighat (ijab dan qabul),

4. Manfaat.

Sedangkan syarat dalam Ijarah adalah:

1. Kerelaan dua belah pihak yang melakukan akad,

2. Ijarah (sewa-menyewa),

3. Manfaat jasa yang disewakan itu diketahui,

4. Upah diketahui,

5. Manfaat jasa yang mubah,

6. Manfaat bisa diambil secara penuh.

7. Manfaat adalah milik sah penjual,

8. Masa sewa nya diketahui. Uang Elektronik (emoney)

\section{B. Tinjauan Umum Perparkiran}

Parkir adalah keadaan tidak bergerak suatu kendaraan yang tidak bersifat sementara. ${ }^{3}$ Parkir liar adalah aktivitas akhir dari suatu perjalanan di lahan yang digunakan kendaraan untuk berlalu lintas, juga bahu jalan baik yang memiliki rambu atau marka maupun yang tidak mempunyai rambu dan tidak ada surat keterangan pemerintah. ${ }^{4}$

Di Indonesia, landasan hukum dalam kegiatan perparkiran diwujudkan dalam Peraturan Daerah Kota Bandung No. 3 Tahun 2008 tentang Penyelenggara Perparkiran. Dan berikut dijelaskan pasal yang berkaitan dengan penelitian ini, yaitu:

Dalam BAB IV pasal 7 ayat 1 tentang pengelolaan tempat parkir bahwasanya:

"Setiap badan hukum/per orangan, dilarang menyelenggarakan parkir umum tanpa ijin."

Dalam pasal 5 ayat 2 tentang penyelenggaraan perparkiran bahwasannya jalan yang digunakan untuk lahan parkir harus memperhatikan hal sebagai berikut:

"Pemasangan tanda-tanda yang jelas berupa rambu parkir dan/atau marka parkir pada Satuan Ruang Parkir (SRP).

\section{Hasil PenElitian DAN PEMBahasanaKetentuan}

A. Akad Ijarah Menurut Fikih Muamalah 
Berdasarkan Teori Ijarah, Akad Ijarah terbagi menjadi dua bagian yaitu, Ijarah yang mengarah kepada pengembalian imbalan ('ala al-a'yan) dari benda-benda material seperti kendaraan, rumah, dan lainnya dan Ijarah yang mengarah kepada upah mengupah yaitu bersifat jasa ('ala al-asykhash), dalam hal ini diatur masalah upah (alujrah), karenanya masalah perburuhan diatur dalam bab Al-Ijarah. Menurut jumhur ulama, rukun ijarah ada empat sebagai berikut:

1. 'Aqid (orang yang berakad)

2. Ujrah (uang sewa atau upah)

3. Sighat (ijab dan qabul)

4. Manfaat

Sedangkan syarat dalam Ijarah adalah:

1. Kerelaan dua belah pihak yang melakukan akad

2. Ijarah (sewa-menyewa),

3. Manfaat jasa yang disewakan itu diketahui,

4. Upah diketahui,

5. Manfaat jasa yang mubah,

6. Manfaat bisa diambil secara penuh

7. Manfaat adalah milik sah penjual,

8. Masa sewa nya diketahui.

B. Pelaksanaan Praktik Pengambilan Sewa Parkir Liar di Pasar Burung Sukahaji Jalan Peta Kota Bandung Berdasarkan Teori Ijarah,

Pelaksanaan parkir di Pasar Burung Sukahaji terbagi menjadi dua, ada parkiran resmi dengan lahan yang disediakan oleh pihak Pasar Burung dan parkiran tidak resmi yang memakan badan jalan di Pasar Burung. Tukang parkir liar di Pasar Burung menarik biaya dari pengendara yang menitipkan kendaraanya, sehingga terjadinya pemungutan secara liar. dalam transaksinya tidak memiliki karcis sebagai bukti pembayaran atau perjanjian untuk menarik biaya dari seseorang yang menitipkan kendaraannya, serta tarif parkir berlaku untuk semua jam, biaya yang ditarik dalam satu kali parkir adalah Rp. 3000.

\section{Tinjauan Akad Ijarah terhadap Pengambilan Sewa Parkir Liar}

Rukun dan Syarat merupakan salah satu yang harus ada dalam sebuah transaksi, yakni rukun dan syarat yang belum terpenuhi dalam praktik pengambilan sewa parkir liar sukahaji adalah sebagai berikut :

Pertama, Sighat (Ijab Qabul), Ijab adalah ungkapan dari orang yang menyewakan atau menerima upah. Sedangkan qabul adalah persetujuan terhadap sewamenyewa tersebut yakni pihak yang memberi upah. Ijab dan qabul tidak harus berupa pernyataan atau ungkapan melainkan dengan tindakan juga termasuk ijab dan qabul. Ijab qabul dalam hal ini ketika seseorang mendapatkan karcis dari tukang parkir kemudian seseorang tersebut mengetahui harus berapa membayar upah kepada tukang parkir dan memberikan uang kepada tukang parkir sambil memberikan karcis yang telah di terima dari tukang parkir.
Berdasarkan wawancara dan observasi yang dilakukan oleh penulis, maka praktik parkir liar di pasar burung sukahaji belum memenuhi rukun Sighat (ijab dan qabul) karena tidak adanya karcis yang diberikan tukang parkir kepada pemilik kendaraan sehingga dalam transaksinya ada unsur keterpaksaan karena adanya ketidakrelaan yakni dari pihak musta'jir. Sebagaimana dalam surat An-Nisa Ayat 29, Allah SWT berfirman :

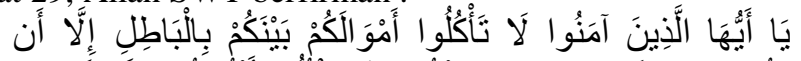

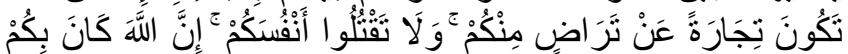
رَحِيمًا

"Hai orang-orang yang beriman, janganlah kamu saling memakan harta sesamamu dengan jalan yang batil, kecuali dengan jalan saling ridho meridhoi." ${ }^{5}$

Kedua, manfaat, spesifikasi manfaat yang dinyatakan harus jelas, termasuk jangka waktunya, dan bisa dikenali dengan spesifikasi atau identifikasi. Berdasarkan wawancara dan observasi penulis, dalam praktiknya tukang parkir liar belum memenuhi manfaat ini karena tidak ada kejelasan dalam jangka waktu sewa nya, sehingga berapa lama kendaraan itu parkir bayarnya sama rata dengan kendaraan yang parkir nya tidak lama.

Ketiga, Maqud Alaihi (objek sewaan), Objek sewaan dalam hal ini adalah lahan parkir yang dipakai untuk pengambilan sewa parkir liar oleh tukang parkir, objek sewaan harus diketahui kepemilikannya secara jelas dan objek sewaan tidak ada yang cacat.

Berdasarkan wawancara dan observasi yang dilakukan penulis serta menelaah studi pustaka tentang perlindungan konsumen menurut akad Ijarah, maka dalam syarat rukun manfaat ini belum terpenuhi karena lahan parkir yang digunakan untuk melakukan parkir liar tersebut adalah milik pemerintah, dan tidak ada Izin Pengelolaan Tempat Parkir (IPTP) dari pihak Dinas Perhubungan. Dari analisis yang telah dipaparkan diatas, dapat disimpulkan bahwasannya praktik parkir liar di pasar burung sukahaji ini belum sesuai dengan akad ijarah sepenuhnya. Dan menurut hukum Islam ditinjau dengan menggunakan akad ijarah, tukang parkir liar di Pasar Burung Sukahaji dikatakan tidak sah. Hal ini dikarenakan masih terdapat rukun yang belum terpenuhi yakni Ujrah, Sighat, Maqud Alaihi dan Manfaat. Seharusnya tukang parkir liar tersebut melakukan pembinaan agar menjadi tukang parkir resmi dengan cara pembinaan terhadap calon tukang parkir sehingga tidak melanggar peraturan

\section{Tinjauan Peraturan Daerah Kota Bandung No. 3 Tahun 2008 tentang Penyelenggara Perparkiran terhadap Pengambilan Sewa Parkir Liar}

Dalam Peraturan Daerah Kota Bandung No. 3 Tahun 2008 tentang Penyelenggara Perparkiran Pasal 7 disebutkan bahwa:

"Setiap badan hukum/perorangan, dilarang menyelenggarakan parkir umum tanpa ijin." 
Dimana yang dimaksud pasal di atas adalah penyelenggaraan tempat parkir harus mempunyai ijin pemerintahh, pada praktiknya penyelenggaraan tempat parkir di pasar burung sukahaji belum sesuai dengan peraturan yang diatas karena tukang parkir di pasar burung meyelenggarakan parkir umum tanpa ijin.

Dalam Peraturan Daerah Kota Bandung No. 3 Tahun 2008 tentang Penyelenggara Perparkiran Pasal 5 ayat 2 disebutkan bahwa:

"Pemasangan pemasangan tanda-tanda yang jelas berupa rambu parkir dan/atau marka parkir pada Satuan Ruang Parkir (SRP)."

Pada praktiknya ditempat parkir tersebut tidak memiliki marka atau pemasangan tanda-tanda berupa rambu parkir dan/atau marka parkir pada Satuan Ruang Parkir (SRP). Berdasarkan wawancara dan observasi penulis, bahwa di parkiran pasar burung sukahaji tidak memiliki karcis sebagai bukti pembayaran akan tetapi tukang parkir tetap menarik biaya kepada pengendara yang menitipkan kendaraannya sehingga terjadinya pemungutan liar. Hal ini tidak memenuhi Peraturan Daerah Kota Bandung No. 3 Tahun 2018 tentang Karcis Parkir karena praktik parkir tersebut belum memiliki IPTP (Ijin Penyelenggaraan Tempat Parkir).

\section{SIMPULAN DAN SARAN}

\section{A. Simpulan}

Berdasarkan pembahasan yang sudah dianalisis, maka penulis dapat menyimpulkan sebagai berikut ini :

1. Ijarah adalah Akad yang objeknya ialah penukaran manfaat untuk masa tertentu, yaitu pemilikan manfaat dengan imbalan, sama dengan menjual manfaat. Menurut jumhur ulama, rukun ijarah ada empat sebagai berikut: orang yang berakad, uang sewa, ijab qabul, dan manfaat. Ijarah dibagi menjadi dua bagian yaitu, Ijarah yang mengarah kepada pengambilan imbalan ('ala al-a'yan) dari benda-benda material seperti kendaraan, rumah, dan lainnya dan Ijarah yang mengarah kepada upah mengupah yaitu bersifat jasa ('ala alasykhash), dalam hal ini diatur masalah upah (alujrah), karenanya masalah perburuhan diatur dalam bab Al-Ijarah.

2. Pelaksanaan parkir di Pasar Burung Sukahaji terbagi menjadi dua, ada parkiran resmi dengan lahan yang disediakan oleh pihak Pasar Burung dan parkiran tidak resmi yang memakan badan jalan di Pasar Burung. Tukang parkir liar di Pasar Burung menarik biaya dari pengendara yang menitipkan kendaraanya, sehingga terjadinya pemungutan secara liar.

3. Berdasarkan hukum Islam, ditinjau dari akad ijarah, praktik parkir liar di Pasar Burung Sukahaji dikatakan tidak sah. Hal ini dikarenakan masih terdapat rukun dan syarat yang belum terpenuhi yakni sighat (ijab qabul), manfaatnya dan 'maqud alaih (objek sewaan). Berdasarkan peraturan daerah kota Bandung no. 3 tahun 2008 tentang penyelenggara perparkiran bahwa tukang parkir liar tidak mempunyai Izin Penyelenggara Tempat Parkir dan menarik biaya tanpa memiliki karcis pembayaran, hal tersebut telah melanggar. Tukang parkir lalai dapat dikenai sanksi berupa hukuman paling lama 3 (tiga) bulan dan/atau denda paling banyak Rp. 50.000.000,- (lima puluh juta rupiah) sebagaimana dalam peraturan daerah Bab XIII tentang ketentuan pidana pasal 22.

\section{B. Saran}

1. Berdasarkan penelitian tentang tinjauan akad ijarah dan peraturan daerah no. 3 tahun 2008 tentang penyelenggaraa perparkiran terhadap pengambilan sewa parkir liar, dapat diberikan beberapa saran sebagai berikut:

2. Ketika mengambil pekerjaan harus mengetahui terlebih dahulu apakah pekerjaan itu sesuai dengan syariat Islam atau tidak. Seharusnya manfaat yang disewakan adalah milik sah penjual jasa atau diizinkan oleh pemilik dan status upah nya harus diketahui, sehingga tidak menimbulkan ketidakrelaan dari salah satu pihak, yakni pihak mustajir.

3. Tukang parkir sebaiknya melakukan pendaftaran terlebih dahulu di dinas perhubungan, dan melakukan pembinaan sehingga akan memiliki izin penyelenggaraan tempat parkir sebagaimana dalam pasal 7 ayat 3 harus mengajukan permohonan tertulis kepada walikota dengan melampirkan syarat-syarat sebagaimana dalam pasal 8. Pihak pemerintah dalam hal ini yakni dinas perhubungan, harus lebih ketat mengawasi tindakan yang dilakukan tukang parkir agar tidak terjadi parkir liar dan pemungutan liar. 


\section{DAFTAR PUSTAKA}

[1] An-Nabhani, Taqyuddin. (1996). Membangun Sistem Ekonomi Alternatif: Perspektif Islam. Surabaya: Risalah Gusti.

[2] Centre park. Apa itu Parkir liar dan peraturan sanksi pidana nya. Retrieved Oktober 23, 2019, From https://centrepark.co.id/apaitu-parkir-liar-dan-peraturan-sanksi-pidananya/.

[3] Departemen Agama Republik Indonesia, Al-Qur'an dan Terjemahannya..., hlm. 83.

[4] Direktur Jendral Perhubungan Darat. Pedoman Teknis Penyelenggaraan Fasilitas Parkir. Retrieved Oktober 10, 2019, From https://www.andalalindkijakarta.com/file/12_272_PEDOMAN_ TEKNIS_FASILITAS_PARKIR.pdf .

[5] Majah, Ibnu. (275 H). Maktabah Al-Syamilah.

[6] Rozalinda. (2017). Fikih Ekonomi Syariah : Prinsip dan Implementasi Pada Sektor Keuangan Syariah. Jakarta: PT Rajagrafindo Persada.

[7] Suhendi, Hendi. (2008). Fiqh Muamalah. Jakarta: PT. Raja Grafindo Persada.

[8] Syafe'i, Rachmat. (2004). Fiqih Muamalah. Bandung : CV Pustaka Setia.

[9] Suhendi, Hendi. (2010). Fiqih Muamalah. Jakarta: Rajawali.

[10] Sahrani, Sohari \& Ruf'ah Abdullah. (2012). Fiqh Muamalah, Bogor: Ghalia Indonesia.

[11] Shalih, Asy-Syaikh. (2015). Terjemahan. Fikih Muyassar : Panduan Praktis Fikih dan Hukum Islam. Jakarta : Darul Haq. 